\title{
頭頸部屈曲テストにおける頸部超音波画像の変化
}

\section{Changes in Ultrasonography Images of the Neck in the Craniocervical Flexion Test}

一瀬 裕介 $^{1)}$ 久保 晃 $^{2)}$

YUSUKE ICHINOSE, RPT, MS ${ }^{1)}$, AKIRA KUBO, RPT, $\mathrm{PhD}^{2)}$

1) Department of Rehabilitation, Social Medical Corporation Hakuaikai, Kamma Memorial Hospital: 2-5 Daikoku-cho, Nasushiobara-shi, Tochigi 325-0046, Japan TEL+81 287-62-0733 E-mail: tppgw635@ybb.ne.jp

${ }^{2)}$ Graduate School of Health and Welfare Sciences, International University of Health and Welfare

Rigakuryoho Kagaku 31(6): 835-839, 2016. Submitted May 24, 2016. Accepted Jul. 21, 2016.

ABSTRACT: [Purpose] We investigated whether ultrasonography can detect changes in the right and left sternocleidomastoid (SCM) and longus colli (LC) muscles between different loads in the craniocervical flexion test. [Subjects and Methods] The subjects were 12 male and 12 female healthy adults. Still images of the subjects at rest, and at 5 different loads in the craniocervical flexion test, were captured by ultrasonography. The thicknesses of SCM and LC, and the cross-sectional area of LC were measured on the images. [Results] The cross-sectional area of LC on the non-dominant side showed a large value compared with that on the dominant side. In the craniocervical flexion test, the cross-sectional areas of both the right and left LC showed significant increases at loads greater than the intermediate level. [Conclusion] Changes in LC muscle activity can be verified on ultrasonography images, suggesting its usefulness as a test feedback method.

Key words: longus colli, craniocervical flexion test, ultrasonography image

要旨：〔目的〕頭頸部屈曲テスト施行時の各負荷段階における左右の頸長筋, 胸鎖乳突筋の変化を, 超音波診断装置 を用いて捉えることができるかを検討した。〔対象と方法〕健常成人男性 12 名，女性 12 名とした．安静時と頭頸部 屈曲テストの 5 段階負荷において, 超音波診断装置を用いて静止画を抽出した. 胸鎖乳突筋筋厚, 頸長筋筋厚, 頸長 筋横断面積を計測した。〔結果〕頸長筋横断面積は利き手側に対して非利き手側において大きな值を示した。頭頸部 屈曲テストにおける頸長筋横断面積は, 中等度以上の負荷において左右とも有意な増加を示した。〔結語〕頸長筋の 超音波画像は, 頸長筋の筋活動変化を確認でき, テストのフィードバック手段としての有用性が示唆された. キーワード : 頸長筋, 頭頸部屈曲テスト, 超音波画像

\footnotetext{
1) 社会医療法人博愛会 菅間記念病院リハビリテーション科：栃木県那須塩原市大黒町 2-5 ( T 325-0046) TEL 0287-62-0733

2) 国際医療福祉大学大学院 医療福祉学研究科

受付日 2016 年 5 月 24 日 受理日 2016 年 7 月 21 日
} 


\section{I.はじめに}

頸部痛は比較的よくみられる症状であり, 約 $70 \%$ の 人が一生のうちになんらかの形で患うと言われてい る ${ }^{1)}$ ，本邦に扔いては，平成 22 年度に厚生労働省が実 施した国民生活基礎調查 ${ }^{2}$ による有訴率は，肩こりが 男性で 2 位，女性で 1 位となっている。肩こりは本邦独 特の表現であり, 欧米では頸部痛 (neck pain), 頸のこ り（stiff neck）と捉えられており，広義での頸部痛とし て考えられる. Wright ら 3)はアメリカに打けるデータで, 頸部痛の年間労働災害補償額は腰痛に次いで 2 番目に高 かったと報告しており，本邦におけるデー夕と類似す る。ささら頸部痛は慢性化しやすく, 再発率も高い4) ことから, 生活の質（quality of life：QOL）に大きく影 響を及ぼすとされており 1 , 理学療法の対象として今後 増加していく可能性が高い.

頸椎は頭部の支持と運動に作用しており, 高い運動性 を有している反面，その運動を制御する安定性が求めら れる。頸椎は深層筋群に覆われており, これらの筋群は 頸椎の分節的安定性に適した形態をしている5). 前方で は頭長筋, 頸長筋（Longus Colli，以下 LC), 前頭直筋が 頸椎前彎の増強を抑制しており, これら深層の屈筋群と 伸筋群が姿勢保持の共同筋として活動することで, 頭部 前方位になることを防いでいる ${ }^{1)}$ ，頸部痛患者は，コン ピュー夕課題を遂行することで頭部が前方に変位するこ とが報告されておりの，日常的な課題遂行下に扔ける頸 部深層筋群の重要性が示されている。本邦においても, 厚生労働省よりVDT（Visual Display Terminals）作業 に㧍ける労衝衛生管理のためのガイドライン7)が策定 されて扔り，産業分野に扔ける労㗢衛生管理として重要 視されている.

頸部痛患者の筋機能に関しては, 筋電図, MRI, 超音 波などを用いた研究 ${ }^{8-14)}$ がなされている。 なかでも筋 電図を用いた研究では, 頸部痛患者による頭頸部の運動 に打いて，LCの活動が抑制されることが示されてい る10).

Jull ら 1) は, 頸部深層屈筋群に対する間接的テストと して頭頸部屈曲テスト (Craniocervical Flexion Test： CCFT）を開発した。 このテストは, 圧バイオフィード バックを用いて運動負荷の調節とモニタリングを行うこ とができ, 頸部痛患者と対照者を鑑別できる10)ことと, トレーニング後の変化に対する感度が高く, アウトカム 指標として適していることが示されている ${ }^{15)}$. CCFT は顎を引くように上位頸椎を屈曲することで，LCを始 めとした頸部深層屈筋群を活動させる運動であり, その 強度を後頭下に挿入した圧センサーによってフィード バックするものである. 安静時の圧を $20 \mathrm{mmHg}$ に設定

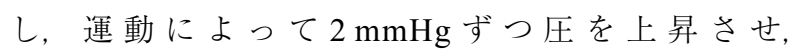
$30 \mathrm{mmHg}$ を上限とする 5 段階のテストであり, 筋の強
さではなく正確性と持久性が重要視される。しかし, 頭 部を後方へ押し付けたり, 胸鎖乳突筋 （Sternoclidomastoid，以下 SCM）や斜角筋を収縮させ たりすることでも圧の変化が起こるため, テストの正確 性の判断が重要になる。 その正確性のフィードバックは, 検者の視診・触診による主観的評価にとどまっており， また CCFT を用いた頸部深層屈筋群の活動性の研究の 多くは, ワイヤー筋電図によって行われている ${ }^{8-10) こ ~}$ とから, 理学療法の臨床場面で用いることは困難である と思われる. Falla ら 10) は CCFT 施行時の筋活動を調查 し, 頸部痛患者では低負荷段階からの LC の活動性低下 と, SCM の活動性増加を報告しており，またコントロー ル群に扔いても $30 \mathrm{mmHg}$ の負荷に扔いては SCM の有 意な増加が認められたと述べている。阂藤ら 16) は, 深 部筋には表在筋とは異なる機能が求められ, 表在筋から 独立した収縮を再学習する必要性を説いて扔り, 超音波 画像を用いてリアルタイムにモニターするバイオフィー ドバック療法が有用であるとしている. CCFTにおいて も，超音波画像を用いて安静時と各負荷段階に扔ける LC およびSCM の変化を捉えることができれば，臨床 に打いて非常に有用な評価手段になり得ると思われる。

安静時に抢けるLCのサイズを, 超音波画像を用いて 測定した研究はいくつか報告されており, 筋厚 (Anterior Posterior Dimension, 以下 APD) および筋横 断面積（Cross Sectional Area，以下 CSA）の計測に扮 いて，その信頼性が示されている 12-14)。四肢, 体幹の 筋のサイズは利き側の影響を受け，左右差があることが 諸氏により報告されており 17-20), 頸部の筋は上肢の利 き側の影響を受けることが予想される。

本研究では, 超音波診断装置を用いて CCFT 施行時 の各負荷段階に扮ける頸長筋の APD, CSA 掞よび SCM の APD の測定が, 臨床における有用なフィード バックとなり得るかを，利き手側，非利き手側を比較し て明らかにすることを目的とした。

\section{II. 対象と方法}

\section{1. 対象}

対象は, 過去に頸部の疾病や外傷などの既往のない健 常成人 24 名（男性 12 名, 女性 12 名, 年齢： $21.5 \pm 2.0$ 歳, 身長: $166.1 \pm 7.9 \mathrm{~cm}$, 体重: $60.4 \pm 10.7 \mathrm{~kg}$, BMI : $21.8 \pm 3.0 \mathrm{~kg} / \mathrm{m}^{2}$, 利き手: 右 22 名, 左 2 名）とした. 対象者には, 書面㧍よび口頭で研究の趣旨と目的を説明 し, 書面で同意を得た。なお，本研究は国際医療福祉大 学研究倫理審査委員会の承認 (承認番号：13-Io-142) を得て実施した。

2. 方法

測定には, 超音波診断装置（sonosite180plus, 
sonosite 社製）を使用し，Javanshir ら 12）の方法に従い， リニア型プローブ $(5-10 \mathrm{MHz})$ を頸部長軸に対して垂 直に当てることでLC および SCM の断面画像を抽出し た。測定高位は，LCが頭長筋と重複せず，境界が鮮明 な画像の抽出が可能であるとされる 15) 第 6 頸椎レベル となるように, 甲状軟骨底部より $2 \mathrm{~cm}$ 下方にマーキン グし，これをランドマークにイメージングした（図 1).

CCFT 施行時の測定は，Jullら1)の方法に準じて実施 した，開始肢位はプラットホーム上での背臥位で，膝関 節屈曲位とした，顔のラインが水平になるようにし，頸 部を長軸に対して 2 等分した線とプラットホームも水平 になるように頸部を中間位とした。被験者によっては頸 部が伸展位となる場合があるので, タオルを必要な高さ になるように折って後頭部の下に置いた。 上位頸椎部に 後頭部に接するように圧バイオフィードバック（スタビ ライザー, Chattanooga 社製) を置き，モニター部分は プラットホームから $40 \mathrm{~cm}$ の高さで, 下顎の直上にな るように固定した，頸部が中間位であることを確認した うえで，圧センサーが $20 \mathrm{mmHg}$ になるまで空気を入れ， これを基準值とし，この時に安静時画像を抽出した，頭 頸部屈曲運動を行うことで, 基準值である $20 \mathrm{mmHg}$ か ら $2 \mathrm{mmHg}$ ずつ, $30 \mathrm{mmHg}$ までの 5 段階の筋収縮を行 い,それぞれにおいて 10 秒間保持し，10 秒経過した時 点での静止画像を抽出した。被験者には事前に, 筋力で はなく，筋の正確性と制御能力のテストであることを十 分に説明した。測定開始前に十分な練習を行い, モ二 ターを見ながら頭頸部を屈曲させ, SCM, 斜角筋の収 縮が起きていないことを被験者自身で確認した。運動の 指示は,「“はい”と領くように」，「後頭部を上方へ滑ら せるように」の 2 種類で統一した。測定は両側の LCに 対して 1 回ずつ, 2 回実施した。安静時と, CCFT 施行 時 5 段階の計 6 条件で得られた画像に対し, 画像解析ソ フト image Jを用いて, LCの APD, CSA, SCMの APD 計測した. APD は最大距離を選択し, APD, CSA ともにアウトラインの高輝度領域は計測範囲に含 まないこととした。

統計解析には, IBM SPSS statistic 20.0 を使用し, 利 き手側, 非利き手側の比較には対応のある $\mathrm{t}$ 検定を行っ た。また CCFTの各負荷段階における LCおよび SCM のパラメータの変化を明らかにするため, 反復測定一元 配置分散分析を行い, その後, Bonfferoni の多重比較検 定を行った，有意水準は 5\%とした。

\section{III. 結 果}

CCFT 施行時の LC および SCM のパラメータ変化を 表 1 に示したＬCのCSAに抽，全ての条件で非 利き手側が有意に大きい值を示した，LC, SCM ともに APD では，いずれの条件においても左右差は認められ

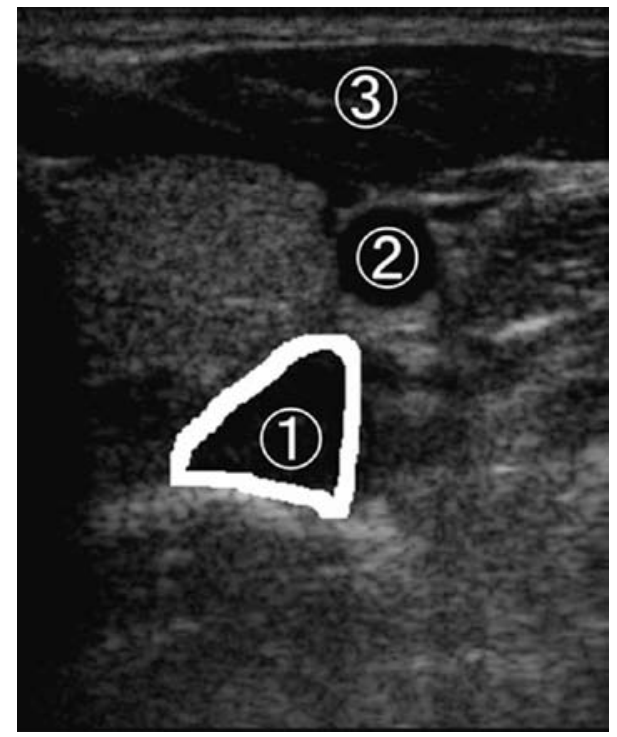

図1 頸長筋超音波画像

(1) Longus Colli (LC) : 頸長筋

(2) Carotid Artery : 内頸動脈

(3) Sternoclidomastoid (SCM)：胸鎖乳突筋

なかった

利き手側 LCにおいては, APD, CSA ともに安静時 に対して $24 \mathrm{mmHg}$ 以上の負荷で有意に増加した。非利 き手側 LCでは, APD, CSA ともに安静時に対して $26 \mathrm{mmHg}$ 以上の負荷で有意に増加した. LC の APD, CSA ともに全体的には安静時もしくは低負荷に対して, 中等度以上の負荷において増加がみられたが, 利き手側, 非利き手側に限らず，安静時に対して低負荷である $22 \mathrm{mmHg}$ においては有意な変化はみられなかった。 $\mathrm{SCM}$ の APD は，どの条件においても有意な変化はみ られなかった。

\section{IV. 考 察}

$\mathrm{LC}, \mathrm{SCM}$ ともにAPDでは左右差がみられなかった が, LC のCSAでは全ての条件で有意差がみられた。 これは，単純に筋のサイズを計測する場合，APDを代 表值とするのではなく，CSAを採用することの有用性 を示している，筋の CSA の左右差について検討された 先行研究は多く散見されており，テニスや野球選手にお ける上肢では利き手側の筋の CSA が大きく，体幹では 非利き手側の方が大きい傾向を示すことが報告されてい る 17-20). 長谷川ら 21) はまた, 投動作, 打動作を伴う競 技者において，非利き手側の内腹斜筋の APD に一側有 意性がみられるが，下肢ではみられなかったと述べてお り，競技特性の影響を示唆している，LCは両側性に収 縮することで頸椎の前彎を立て直し, これは頸椎の安定 化にきわめて重要な役割を果たすとされている ${ }^{22)}$. し かし, スポーツや日常生活において, 左右対称な動作は 
表 1 CCFT 施行時の頸長筋パラメータ変化

\begin{tabular}{|c|c|c|c|c|c|c|c|}
\hline & & 安静時 & $22 \mathrm{mmHg}$ & $24 \mathrm{mmHg}$ & $26 \mathrm{mmHg}$ & $28 \mathrm{mmHg}$ & $30 \mathrm{mmHg}$ \\
\hline \multirow[t]{6}{*}{ LC } & APD $(\mathrm{cm})$ & & & & & & \\
\hline & 利き手側 & $0.87 \pm 0.17$ & $0.91 \pm 0.20$ & $0.93 \pm 0.19^{*}$ & $0.94 \pm 0.19 * *$ & $0.96 \pm 0.20^{* *}$ & $0.96 \pm 0.17 * *$ \\
\hline & 非利き手側 & $0.92 \pm 0.15$ & $0.93 \pm 0.15$ & $0.96 \pm 0.14$ & $1.00 \pm 0.16^{* * \S}$ & $1.02 \pm 0.15^{* * \S}$ & $1.01 \pm 0.15^{* *}$ \\
\hline & $\operatorname{CSA}\left(\mathrm{cm}^{2}\right)$ & & & & & & \\
\hline & 利き手側 & $0.81 \pm 0.16$ & $0.88 \pm 0.19$ & $0.91 \pm 0.18^{* *}$ & $0.95 \pm 0.18^{* * \dagger \dagger \S}$ & $0.97 \pm 0.22 * * \dagger \uparrow \S \S$ & $0.97 \pm 0.21 * * \dagger \dagger$ \\
\hline & 非利き手側 & $0.93 \pm 0.19$ ? & $0.98 \pm 0.21^{9}$ & $1.02 \pm 0.20$ & $1.06 \pm 0.19^{* * \dagger \uparrow}$ & $1.09 \pm 0.22 * * \dagger 9$ & $1.09 \pm 0.22 * * \dagger+\uparrow$ \\
\hline \multirow[t]{3}{*}{ SCM } & APD $(\mathrm{cm})$ & & & & & & \\
\hline & 利き手側 & $0.97 \pm 0.23$ & $0.97 \pm 0.23$ & $0.98 \pm 0.23$ & $0.99 \pm 0.22$ & $0.97 \pm 0.20$ & $0.98 \pm 0.22$ \\
\hline & 非利き手側 & $0.98 \pm 0.22$ & $1.00 \pm 0.22$ & $0.99 \pm 0.20$ & $0.99 \pm 0.21$ & $1.00 \pm 0.20$ & $1.01 \pm 0.20$ \\
\hline
\end{tabular}

CCFT: Craniocervical Flexion Test, LC: Longus Colli, SCM: Stenoclidomastoid, APD: Anterior Posterior Dimension, CSA: Cross Sectional Area. 安静時との比較 $(* *: \mathrm{p}<0.01), 22 \mathrm{mmHg}$ との比較 $\left(^{\dagger}: \mathrm{p}<0.05\right.$, $\left.{ }^{\dagger \dagger}: \mathrm{p}<0.01\right), 24 \mathrm{mmHg}$ との比較 $(\S: \mathrm{p}<0.05$, $\S \S: \mathrm{p}<0.01)$, 利き手側と非利き手側間の比較 $(\rrbracket: p<0.01)$.

ほとんどなく，頸部においては上肢の活動に対する姿勢 制御や，カップリングモーションなど，高度な動きを求 められる。このような状況で，LCの左右対称な筋収縮 が得られることは困難であることが予想される，和田 ら 23) は, 肩関節屈曲運動時の体幹深部筋の反応時間を 測定し, 非挙上側の腹横筋, 内腹斜筋, 多裂筋が有意に 早く活動することを報告している，LCも，上肢挙上運 動に扔けるフィードフォワード機構としての機能が示さ れている9)。スポーツ競技者でなくても，日常生活に扔 いて利き手を優位に使用していることは容易に想像でき 非利き手側 LC の一側有意性や，フィードフォワード機 構としての活動の早さが存在するものと思われる，以上 より，単純に左右差を比較するよりは，利き手を考慮す るべきであり，本研究では非利き手側に扔いて CSAが 有意に大きな值を示した。これは，スポーツや日常生活 に扔ける利き手側上肢の動きに対して, 非利き手側 LC がフィードフォワード機構として, また頸椎分節的安定 化機構として優位に活動していることが考えられる。

次に CCFT 施行時の各パラメータの変化について考 察する. Falla ら ${ }^{10)}$ は筋電図を用いて CCFT 施行時の筋 活動を調查し, 頸部痛患者では低負荷段階からの LC の 活動性低下と, SCM の活動性増加を報告している。 ま た，コントロール群に扔いても $30 \mathrm{mmHg}$ の負荷に扔い ては SCM の有意な活動性増加を認めたと述べている. 本研究では $30 \mathrm{mmHg}$ の負荷に扔いても SCM の APD に有意な増加はみられなかった。 CCFTに扔ける SCM の活動は LC の代償的活動と考えられるが, 本研究結果 ではAPDの変化として捉えることはできなかった，超 音波画像を用いた CCFT の正確性のフィードバックは, LC の変化を捉えることが望ましいと思われる．

LC は，両側とも APD, CSAに打いて有意な増加が みられたが, その多くは安静時に対する運動時の増加, もしくは低負荷に対する中等度以上の負荷での増加であ り，各負荷段階間に打いては必ずしも変化がみられな
かった。しかし，安静時に対しての変化はみられている ため, LCが活動しているか否かの判断は可能である. これは CCFT 施行時に扔ける LC の筋活動の正確性の判 断として, 臨床応用という観点において非常に有用であ ると思われる。また，LCのCSAでは全ての負荷段階 に扔いて左右差が見られたが，APDではいずれに执い ても差は見られなかった，APDは簡便な計測が可能で あるが，左右差を比較する場合，CSA の計測が望まし いことが示唆された

本研究では APD, CSA の増加をLCの筋活動と捉え て実施した。これまでに APD と筋活動の関係について は様々な報告がされており, McMeeken ら 24) は, 腹横 筋の APD と筋活動量との間に相関があることを述べて いるが, Hodges ら 25) や Brown ら 26) は逆説的に, 直線 関係はないと述べている，頸部の筋に扔けるこのような 先行研究は見当たらないが, 直線関係となることは考え がたい，最近の研究では，せん断波エラストグラフィが 用いられて抢り, 筋硬度評価と筋活動の関連が示唆され ている 27). 中村ら 28) も, APD 増減よりも筋硬度増減 の方が発揮筋力や筋活動量の推定に有効である可能性を 述べており，LCの評価についても今後の検討が必要で ある。

超音波画像によって得られる APDやCSA から, 筋 活動量を測ることには限界があることが考えられる。し かし, 今回の結果でも分かるように, 安静時と比較して 収縮が得られているかどうかについての妥当性は過去の 研究によって明らかであり, Hodges ら 25) も等尺性収縮 に扔ける個々の筋の同定に対する有用性を示唆してい る。超音波画像を用いて LC の APD や CSA を計測する ことは, CCFT 施行時の LC の活動をフィードバックす る上で, 利き手側については $24 \mathrm{mmHg}$ 以上, 非利き手 側については $26 \mathrm{mmHg}$ 以上の負荷に打いて有用である ことが示唆された. 


\section{引用文献}

1) Jull G, Sterling M, Falla D, et al.: 頸部障害の理学療法マ ネージメント。新田 収・他（監訳），ナップ，東京，2009， pp3-5, 136-138.

2) 厚生労働省大臣官房統計情報部 : 平成 26 年国民生活基礎調 査（平成 25 年）の結果から. http://www.mhlw.go.jp/toukei/ list/d1/20-21-h25.pdf（閲覽日 2015年1月 19 日）。

3) Wright A, Mayer T, Gatchel R: Outcomes of disabiling cervical spine disorders in compensation injuries. A prospective comparison to tertiary rehabilitation response for chronic lumbar spinal disorders. Spine (Phila Pa 1976), 1999, 24(2): 178-183.

4) Gore DR, Sepic SB, Gardner GM, et al.: Neck pain: A longterm follow-up of 205 patients. Spine (Phila Pa 1976), 1987, 12(1): 1-5.

5) Boyd-Clark LC, Briggs CA, Galea MP: Muscle spindle distribution, morphology, and density in longus colli and multifidus muscles of cervical spine. Spine (Phila Pa 1976), 2002, 27(7): 694-701.

6) Falla D, Jull G, Russell T, et al.: Effect of neck exercise on sitting posture in patients with chronic neck pain. Phys Ther, 2007, 87(4): 408-417.

7) 厚生労働省：新しい「VDT作業における労衝衛生管理の ためのガイドライン」の策定について. http://www.mhlw. go.jp/houdou/2002/04/h0405-4.html（閲覧日2015年 1 月 19 日).

8) Jull G, Kristjansson E, Dall'Alba P: Impairment in the cervical flexors: A comparison of whiplash and insidious onset neck pain patients. Man Ther, 2004, 9(2): 89-94.

9) Falla D, Jull G, Hodges PW: Feedforward activity of the cervical flexor muscles during voluntary arm movements is delayed in chronic neck pain. Exp Brain Res, 2004, 157(1): 43-48.

10) Falla D, Jull G, Hodges PW: Patients with neck pain demonstrate reduced electromyographic activity of the deep cervical flexor muscles during performance of the craniocervical flexion test. Spine (Phila Pa 1976), 2004, 29(19): 2108-2114.

11) Cagnie B, Dolphens M, Peeters I, et al.: Use of muscle functional magnetic resonance imaging to compare cervical flexor activity between patients with whiplash-associated disorders and people who are healthy. Phys Ther, 2010, 90(8): 1157-1164.

12) Javanshir K, Mohseni-Bandpei MA, Rezasoltani A, et al.: Ultrasonography of longus colli muscle: A reliability study on healthy subjects and patients with chronic neck pain. J Bodyw
Mov Ther, 2011, 15(1): 50-56.

13) Cagnie B, Derese E, Vandamme L, et al.: Validity and reliability of ultrasonography for the longus colli in asymptomatic subjects. Man Ther, 2009, 14(4): 421-426.

14) Jesus FM, Ferreira PH, Ferreira ML: Ultrasonographic measurement of neck muscle recruitment: A preliminary investigation. J Man Manip Ther, 2008, 16(2): 89-92.

15) Jull G, Trott P, Potter H, et al.: A randomized controlled trial of exercise and manipulative therapy for cervicogenic headache. Spine (Phila Pa 1976), 2002, 27(17): 1835-1843.

16) 斎藤昭彦，村上幸士：超音波画像を用いた体幹の評価．理 学療法, 2014, 31(1): 41-47.

17) 長谷川伸, 小野高志：野球投手の筋厚の非対称性とボール スピードの関係. 体力科学, 2012, 61(2): 227-235.

18）長谷川伸, 館 俊樹, 佐々木宏・他: 大学野球選手の回旋 腱板筋ならびに三角筋の形態扔よび筋力特性. 体力科学, 2003, 52(4): 407-419.

19) 長谷川伸, 館 俊樹, 齋藤恵一・他 : 野球投手の回旋腱板 筋（rotator cuff muscles）と三角筋の MRI法による筋量分析 とその筋力特性. 体力科学, 2004, 53(5): 483-492.

20) Silva RT, Gracitelli GC, Saccol MF, et al.: Shoulder strength profile in elite junior tennis players: Horizontal abduction and abduction isokinetic evaluation. Br J Sports Med, 2006, 40(6): 513-517.

21) 長谷川伸, 船津京太郎：投動作，打動作を伴う競技者の筋 厚に扔ける一側優位性. 体力科学, 2013, 62(3): 227-235.

22) Kapandji AI: カパンジー機能解剖学 III 脊椎・体幹・頭部. 塩田悦人 (訳), 医歯薬出版, 東京, 2011, pp238-239.

23) 和田裕介, 金岡恒治, 竹村雅裕 - 他：上肢挙上運動時の 体幹深部筋の筋反応時間解析. 日本臨床スポーツ医学会誌, 2013, 21(2): 396-402.

24) McMeeken JM, Beith ID, Newham DJ, et al.: The relationship between EMG and change in thickness of transversus abdominis. Clin Biomech (Bristol, Avon), 2004, 19(4): 337-342.

25) Hodges PW, Pengel LH, Herbert RD, et al.: Measurement of muscle contraction with ultrasound imaging. Muscle Nerve, 2003, 27(6): 682-692.

26) Brown SH, McGill SM: A comparison of ultrasound and electromyography measures of force and activation to examine the mechanics of abdominal wall contraction. Clin Biomech (Bristol, Avon), 2010, 25(2): 115-123.

27) 稲見崇孝, 清水卓也, 三木貴弘：ヒ卜骨格筋に打ける超音 波エラストグラフィの基礎理論と臨床応用. 日本整形外科 スポーツ医学会雑誌, 2014, 34(1): 2-10.

28) 中村雅俊, 市橋則明: 超音波画像を用いた筋組織の評価. 理学療法, 2014, 31(1): 24-31. 